\title{
Study on Technical Measures of Romashkino Oil Field after Entering Ultra-High Water Cut Stage
}

\author{
Liuli Lu ${ }^{1,2}$, Zhibin Liu ${ }^{1}$, Haohan Liu ${ }^{1,3 *}$, Yongqin Yan ${ }^{1}$ \\ ${ }^{1}$ School of Graduate of Southwest Petroleum University, Chengdu, China \\ ${ }^{2}$ Geological Exploration and Development Institute of Chuanqing Drilling Engineering Co., Ltd., Chengdu, China \\ ${ }^{3}$ Sichuan College of Architectural Technology, Deyang, China \\ Email: ${ }^{*}$ tsinghua616@163.com
}

Received May 6, 2012; revised June 6, 2013; accepted June 14, 2013

Copyright (C) 2013 Liuli Lu et al. This is an open access article distributed under the Creative Commons Attribution License, which permits unrestricted use, distribution, and reproduction in any medium, provided the original work is properly cited.

\begin{abstract}
Romashkino oil field has large oilfield area, small formation dip, many reservoir layers, wide oil-water transition zone and complicated sedimentary environment. Since development, 3 overall development plannings and adjustments of individual block have been established. This achieves a high oil production. However, the recoverable reserves of major oil layer with high production become smaller and smaller and the water cut increases over time, the production ability of oil layer decreases. The development status of oil layer of mining siltstone, oil-water transition zone and oil layer with upswept injected water cannot be changed under present dilute well network condition, because there is no reinforced measurement to water well. This results the low oil production of Romashkino oil field. In order to improve oil production rate and reach the designed oil recovery, Romashkino oil field has been implemented many added cuttings since development. Resent researches about Romashkino oil field show: in later oilfield development stage, sidetrack and lateral drilling horizontal wells technology is very reasonable; formation hydraulic fracturing technology has been widely used in recent years; in tertiary oil recovery, sweep efficiency and flooding efficiency related technologies have been taken. This offers reference and guidance for the effective and reasonable oil field development in later period.
\end{abstract}

Keywords: Romashkino Oil Field; Geological; Development; Technical Measures

\section{Introduction}

Romashkino oil field lies in Tatarsta. It was found in 1948, and began industrial development in 1952. In 1954, Romashkino oil field began to inject water and it was a typical multi-layer oil field [1,2]. The oily area of Romashkino oil field is $4255 \mathrm{~km}^{2}$, geological reserves is 45 $\times 108 \mathrm{~m}^{3}$, the recoverable reserves is $24 \times 1088 \mathrm{~m}^{3}$, and the oil recovery is $53 \%[3,4]$. At present, this oilfield is in the production decline stage. In 1997, the crude oil production of Romashkino oil field is $1500 \times 10^{4} \mathrm{~m}^{3}$, the water cut is 0.88 , the cumulative oil production is $20.3 \times$ $10^{8} \mathrm{~m}^{3}$, the recovery degree is $45.1 \%[5,6]$. The location map is shown in Figure 1.

\section{Romashkino Oil Field Geology and Development}

\subsection{Tectonic}

The area of Romashkino oil field is large and the forma-

${ }^{*}$ Corresponding author. tion dip is small, the tectonic area is $4500 \mathrm{~km}^{2}$, where the oil-water transition zone area is $70 \%$ of the total area, the formation dip is smaller than $0.5^{\circ}$, and only reaches $2^{\circ}$ in the side of south and west. The oil-bearing area of Devonian D-I layer is $4255 \mathrm{~km}^{2}$, tectonic high-point located in

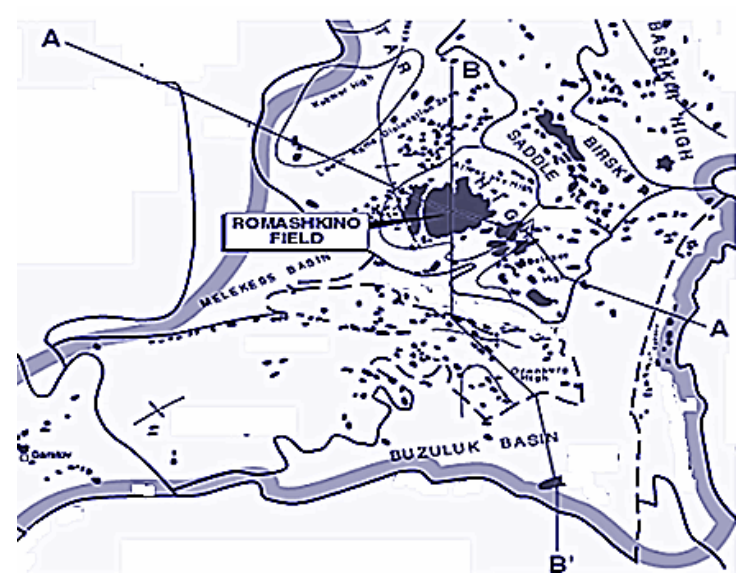

Figure 1. Location map of Romashkino oil field. 
$1535 \mathrm{~m}$ below the sea leve [7-9] (see Figures 2 and 3) (North: 1480 - 1482 m, South: 1489 - 1490 m).

\subsection{Sedimentary Facies}

The oilfield stratigraphic section is composed of the Precambrian, Devonian, Carboniferous and Permian strata, the total sediment thickness is 2000 meters, in which car- bonate sediment thickness is about $1500 \mathrm{~m}$, the thickness of the terrigenous is about 500 meters, where $89 \%$ of the proved reserves located in the Paxi Ya group DI sand layer and Ke Nuofu group D-0 sand layer of the Upper Devonian. The depositional environment of the sandstone reservoir is mainly the delta plain distributary channel, The lithology consists of quartz sandstone, siltstone, mudstone and limestone.

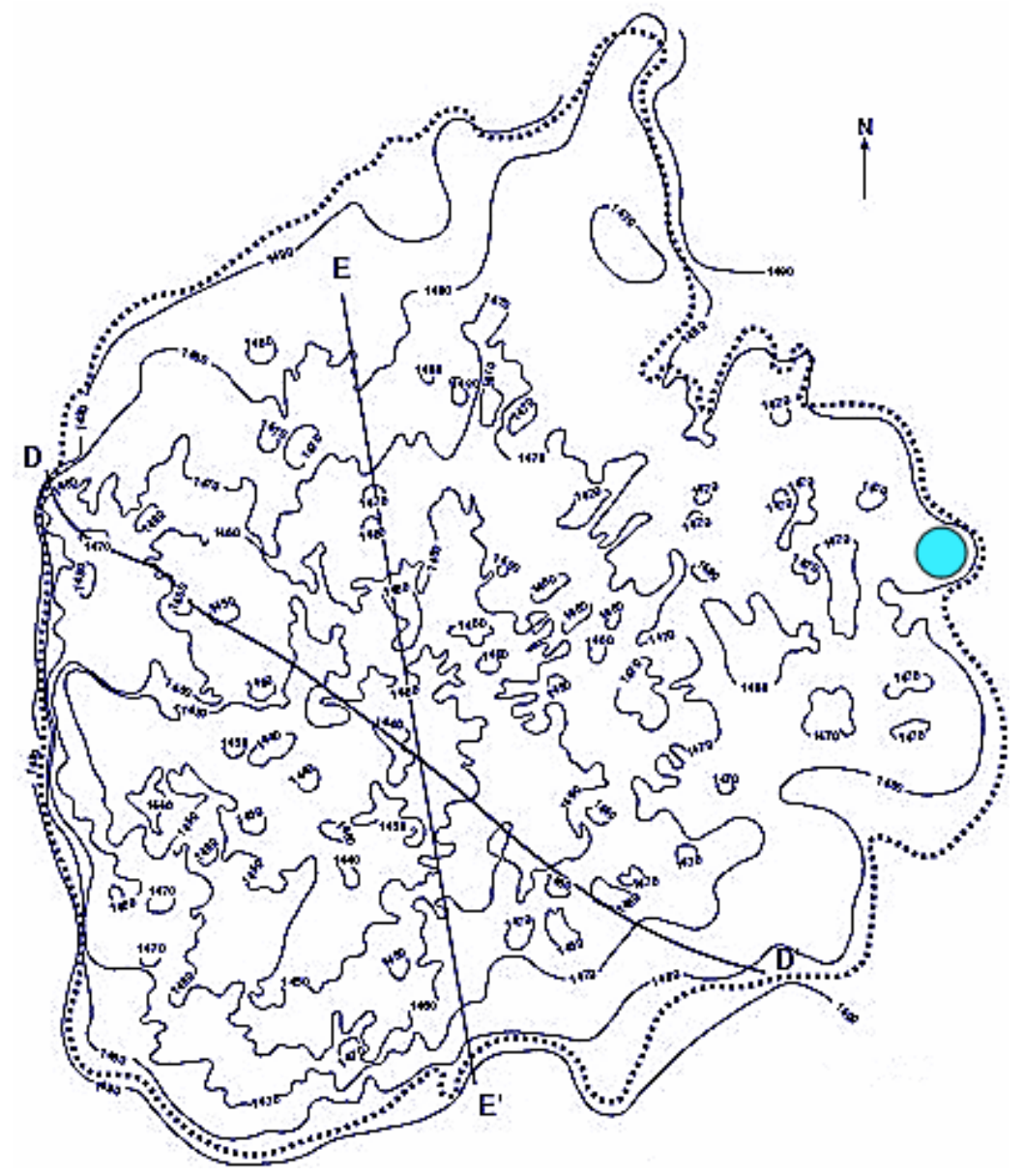

Figure 2. Formation top structure of Romashkino oil field.

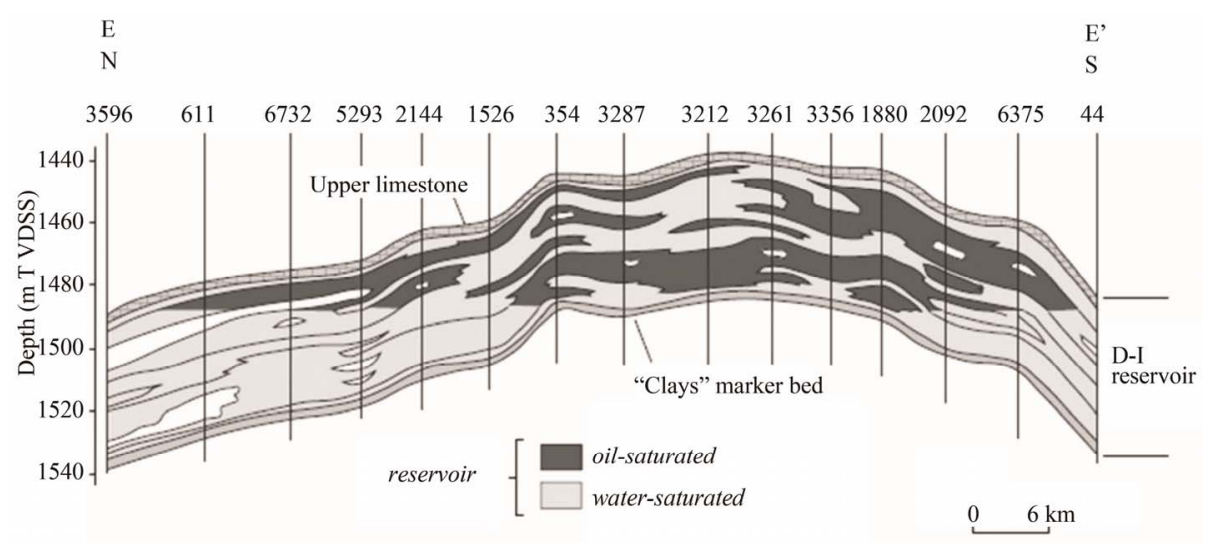

Figure 3. Cross-sectional view of D-I oil layer of Romashkino oil field. 


\subsection{Reservoir Properties}

The proven reservoirs of the oil field are 421.22 oil layers are established. The main oil production layer is D-I layer, the burial depth ranges from $1650 \mathrm{~m}$ to $1850 \mathrm{~m}$. the oil layer temperature is 37.8 Degrees Celsius, the original formation pressure is $16.3-18.2 \mathrm{MPa}$, and the OOIP is $45 \times 10^{8} \mathrm{t}$, other parameters are shown in Tables 1 and 2.

Fluid properties

The following shown parameters are the major parameters of the fluid properties of the production layer of Romashkino oil field.

Original formation pressure: 16.3 - 18.2 MPa;

Saturation pressure: 8.5 - $9.5 \mathrm{MPa}$;

Original gas-oil ratio: $40-65 \mathrm{~m}^{3} / \mathrm{t}$;

Oil density: $0.858 \mathrm{~g} / \mathrm{cm}^{3}$;

Viscosity: 2.6 - $4.5 \mathrm{mPa} \cdot \mathrm{s}$;

Wax content: $3.2 \%$;

Sulfur content: $1.3 \%$;

The original reservoir temperature: $37.8^{\circ} \mathrm{C}$;

The original water saturation: $17 \%-21 \%, 19 \%$ in average;

In a word, the major characteristics of Romashkino oil field are the followings: large area; big the formation dip; many oil layers; wide oil-water transition zone and complicated sedimentary environment.

\section{Romashkino Oil Field Development Characteristics}

\subsection{Oil Development Design}

Since development in 1952, Romashkino oil field has been made three total development program $[11,12]$.

1) The first total development program (in 1956)

According to the geological structure, reserve property and oil-water interface factors, Romashkino oil field is cutting into 21 development zone with water injection wells, the yearly oil production is $5400 \times 10^{4}$ ton. The injection and production of D-I layer is reasonable, the bottom-hole pressure of production well is $12.5 \mathrm{MPa}$, the wellhead pressure of injection well is $6 \mathrm{MPa}$, water line pressure is 17.5 $\mathrm{MPa}$ (see Figure 4).

2) The second total development program (in 1966)

The second total development program declined the cutting distance, reinforced the development of oil layer with low and middle permeability. The main idea of this program is to keep stable production after entering high oil production; move the water line in completely flooded area, reservoir with good connectivity and homogeneous region; increase 50 percent oil production. The designed oil recovery of each cutting section is $40 \%$ to $55 \%$. In order to solve the hierarchical differences, the development program formulates to take separate water injection and oil production.

3) The third total development program (in 1976 to

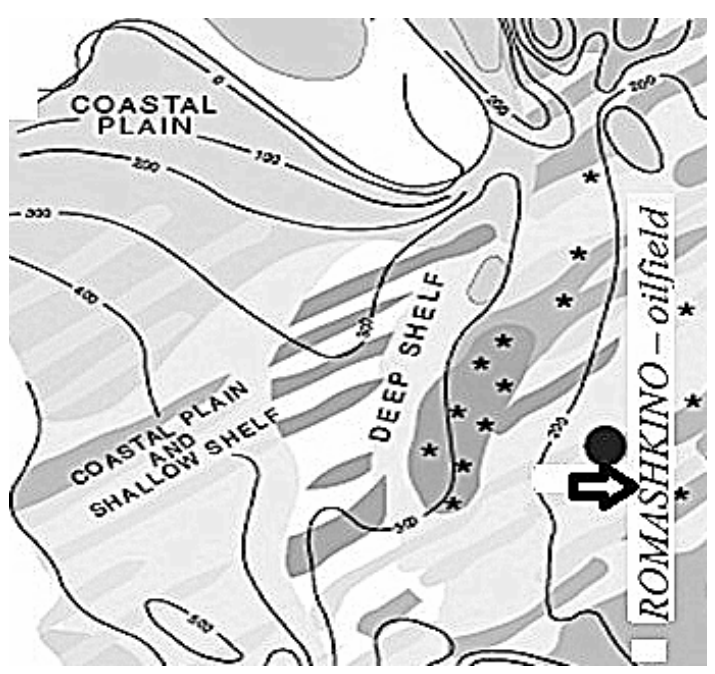

Figure 4. Depositional environment of DI-D0 oil layer.

Table 1. Data of BXY group D-I layer.

\begin{tabular}{cccc}
\hline D-I layer & $\begin{array}{c}\text { Thickness of production } \\
\text { layer (m) }\end{array}$ & $\begin{array}{c}\text { permeability } \\
(\mathrm{mD})\end{array}$ & $\begin{array}{c}\text { Porosity } \\
(\%)\end{array}$ \\
\hline a & $1.8-7.1$ & $157-589$ & $14-23$ \\
b1 & 2.8 & 541 & 22 \\
b2 & 2.2 & 317 & 19 \\
b3 & 2.9 & 411 & 22 \\
v & $1.9-3.2$ & $142-731$ & $13-24$ \\
g1 & 2.9 & $300-400$ & 20 \\
g2-3 & 6.6 & 824 & 21 \\
d & $2-3.7$ & $156-553$ & $14-22$ \\
\hline
\end{tabular}

Table 2. Data of main reservoir.

\begin{tabular}{|c|c|c|c|c|c|}
\hline project & D-I & D-0 & project & D-I & D-0 \\
\hline $\begin{array}{l}\text { Total thickness of } \\
\text { reservoir } / \mathrm{m}\end{array}$ & $20-50$ & $20-40$ & permeability $/ \mathrm{mD}$ & $142-824$, average 375 & $100-800$, average 300 \\
\hline $\begin{array}{l}\text { Effective thickness of } \\
\text { reservoir/m }\end{array}$ & $3.7-16.6$, average 8.9 & $<4$, average 3.2 & porosity $/ \%$ & $13-24$, average 19 & $10-22$, average 18 \\
\hline Net-gross ratio & 0.56 & - & Initial oilsaturation & $17-21$, average 19 & - \\
\hline
\end{tabular}


1977)

The water injection system is further reinforced, the water flooded area is enlarged, the additional wells are kept drilled, the wells network is encrypted and the production decline rate is controlled to reach the designed oil recovery. To reinforce water injection system needs the ratio of injection well and production well to be 1:3; for the independent well network with connectivity layer, the upper reservoir injection pressure should be higher than the lower reservoir; selective injection in the oil water transition band.

4) Key adjustment in five development Zones

In 1986, five development zones in the later development period of Romashkino oil field were mainly adjusted.

1) Establish separate point-like injection system in the discontinuous oil layer with low oil production reservoir of Rakhmanov block; carry out supplementary cutting in the high production oil layer and establish separate massive water injection system;

2) Establish supplementary cutting wells aims to develop periodic water injection in the A oil layer of Aliyefu and Dongsuyefu development zone;

3) Establish stratified water injection system and supplementary cutting wells in the Qishiming development zone;

4) Use the $600 \times 600 \mathrm{~m}$ well network in the Saernuofu development zone and carry out side water injection and horizontal cutting;

5) In addition, carry out phased drilling in the low permeability layer of Qishiming development zone; encrypt well spacing density to $300 \times 600 \mathrm{~m}$ in the later period of Saernuofu development zone; do not drill well in the area with siltstone thickness less than $2 \mathrm{~m}$ and without water injection system.

\subsection{Division of Oilfield Development Stages}

After introducing statistics to the Romashkino oil field gives Figures 5 and 6.

From Figures 5 and 6, we divide the Romashkino oilfield development stage into four stages, they are:

1) the first stage (1952-1969): incensing oil production stage;

2) the second stage (1970-1975): stable oil production stage;

3) the third stage (1976-1992): oil production decline stage;

4) the fourth stage (since1993): decline slowed down stage.

\subsection{Characteristics of Oil Field Development}

Characteristics of oil field development are shown in Figures 7-9.

Figure 7 shows: in the second stage of development, the water cut characteristic curve is a line, water cut of oilfield increases steadily. With the implementation of various adjustment measures of the oilfield, a downward trend of the line slope takes on; Figure 8 shows the second characteristic curve can be divided into three line section: the first line section means the completely development of oilfield blocks, water cut increases steadily; the second line section means the water cut increase faster and faster, because of the imperfect injection and production systems; in the third line section, the water cut keeps 0.87 with the implementation of different measures.

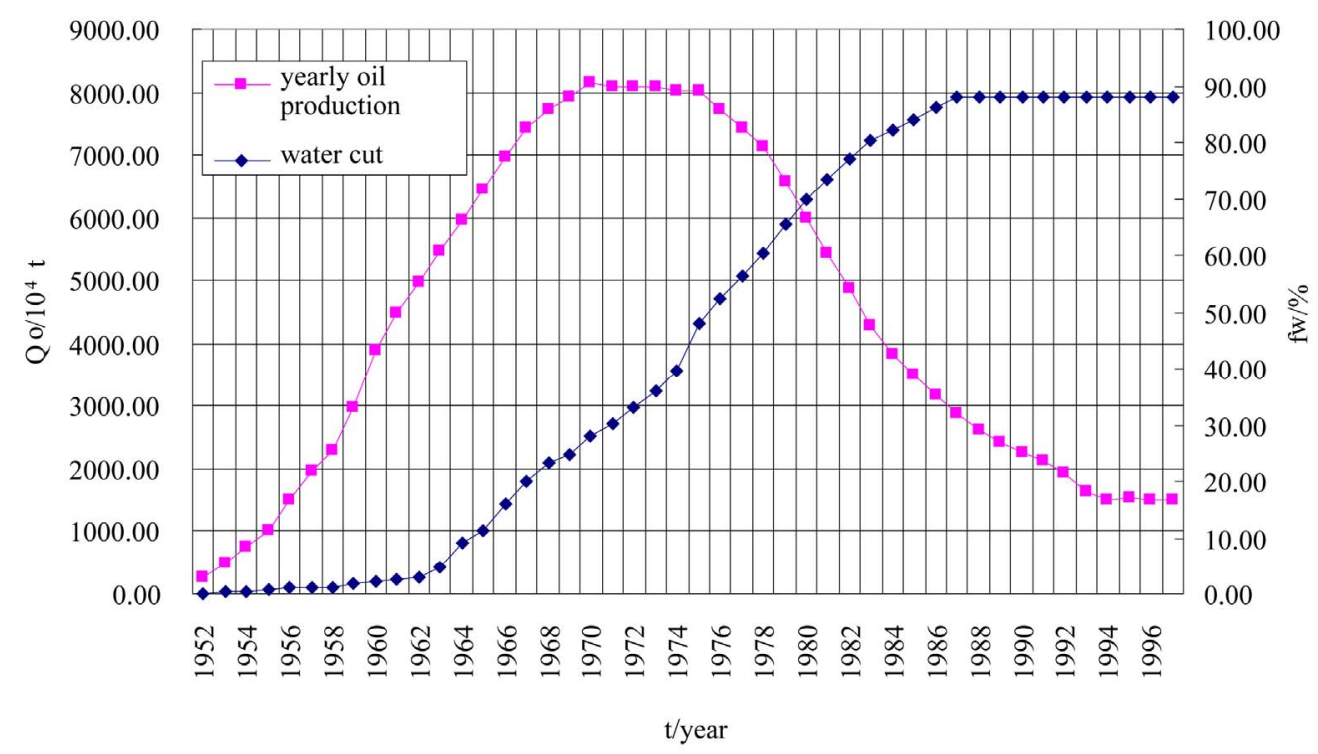

Figure 5. Yearly oil production and water cut of Romashkino oil field. 


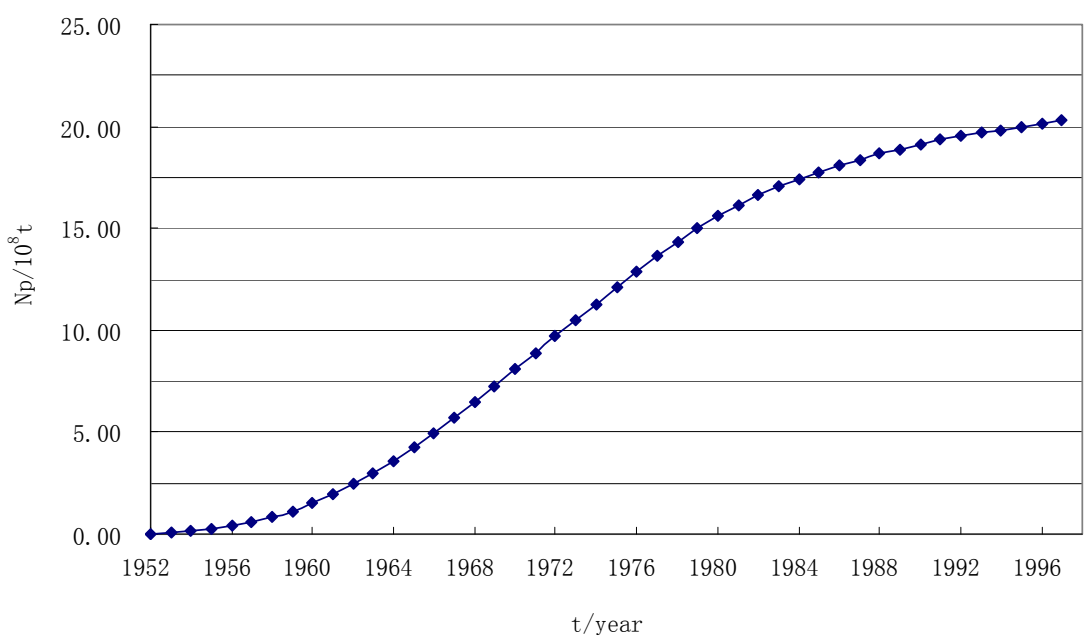

Figure 6. Cumulative oil production of Romashkino oil field.

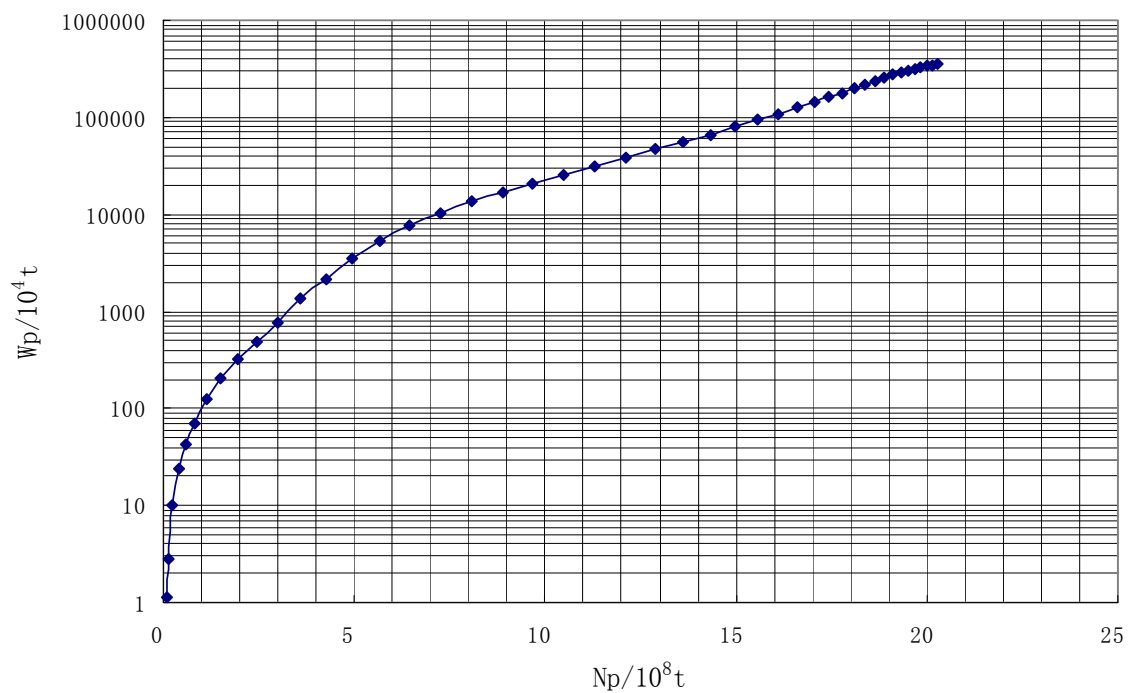

Figure 7. First-type water drive curve.

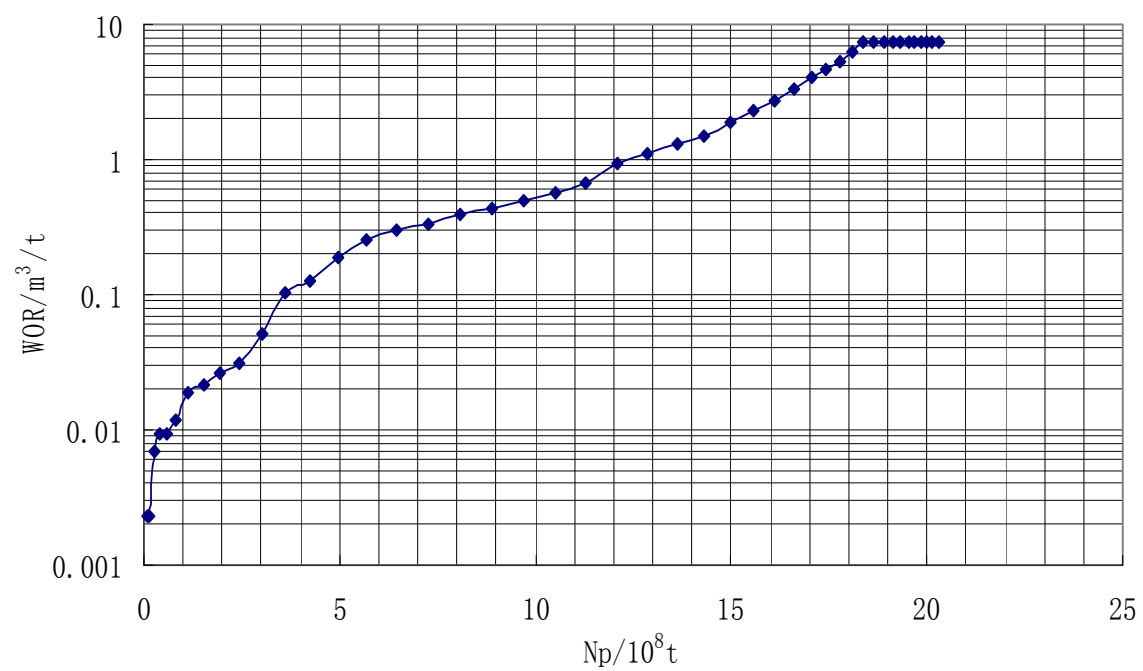

Figure 8. Second-type water drive curve. 


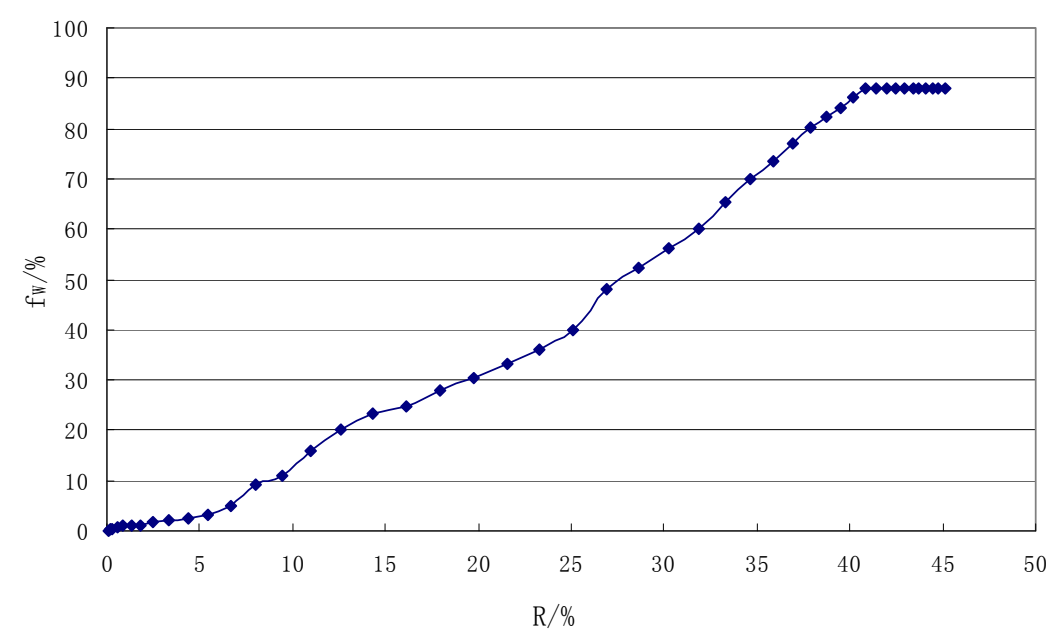

Figure 9. Relation curve between recovery degree and water cut.

\section{Technical Measures of Romashkino Oilfield after Entering Ultra-High Water Cut Stage}

\subsection{Oilfield Development Problems}

1952, Romashkino oil field started to develop, and the oil production increased by time. In 1970, the oil production reached maximum-81.50 million tons. From 1976 to 1979 , the oil production declined from 77.75 million tons to 68 million toms, the yearly declining rate is $2.8 \%$ $5.9 \%[10-12]$.

\subsection{Improvement of Major Technical Measures of Oilfield Development}

1) Improve development system and enhance oil recovery

In order to enhance oil production rate and reach the designed oil recovery, the Romashkino oilfield carried out many additional cutting measurements, form 23 to 59 . Because the cutting width is narrow, the oil layer volume with effective water sweep increases $20 \%$, and the oil production rate increases relatively. Considering the heterogeneity, point-like injection, selective filling and mobile water injection, as well as part of the stratified water injection of injection well with different pressure can be carried out.

2) Develop with new wells in new blocks

The development process of Romashkino oilfield begins with middle high production area, and expands the development area step by step. Since 1952, 1 - 2 new development Zone has been put into operation. In the major development stage, production wells are increased to $370-600$ per year, and the injection wells increased to 70 - 100. After 1964, Romashkino oilfield began to drill supplementary well and encrypt the original well pattern.

3) Take different measures to reduce water production
The water cut of Romashkino oilfield increase slowly, and the fluid production and water production is low. This is related to the oil velocity and many measurements and adjustments.

1) Close the water well with high water cut;

2) Block high water cut layer;

3) Drill additional wells in low water cut area and improve oil production of oil well with little water;

4) Change the fluid flow direction by periodic water injection and adjust the water injection profile of water injection well.

Researches in recent years show: in later oilfield development stage, sidetrack and lateral drilling horizontal wells technology is very reasonable; formation hydraulic fracturing technology has been widely used in recent years; in tertiary oil recovery, sweep efficiency and flooding efficiency related technologies have been taken.

\section{REFERENCES}

[1] J. P. Riva Jr., "The Petroleum Resources of Russia and the Commonwealth of Independent States," The Former Soviet Union in Transition, Vol. 2, 1993, pp. 461-476.

[2] A. Loppinet, S. Lakovlet and Ph. Glenat, "Five Years of Injection of Hydroxyethylcellulose-An Ecological Pure Product for Enhanced Oil Recovery in the Field of Romashkino," Proceedings of SPE Offshore Europe Conference, Aberdeen, 23-24 October 1999, pp. 39-43.

[3] H. Q. Chao, "Development of Large and Giant Oil Gas Fields in Russia," Vol. 1, Petroleum Industry Press, Beijing, 1998, pp. 46-74.

[4] R. G. Abdulmazitov, A. F. Blinov, et al., "Reservoir Modeling for Giant Romashkino Field (Problems and Solutions)," Proceedings of SPE European Petroleum Conference, Paris, 24-25 October 2000, pp. 653-655.

[5] T. Yusupova, R. Muslimov, G. Romanov, et al., "The Impact of Interfacial Phenomena on the Efficiency of Oil Recovery (A Case of the Heterogeneous Strata of the 
Romashkino Oil Field, Tatarstan)," Canadian International Petroleum Conference, Calgary, 10-12 June 2003. doi: $10.2118 / 2003-036$

[6] X. J. Wen and F. R. Li, "Overview of Romashkino Field Development," Foreign Oil Field Engineering, Vol. 26, No. 12, 2010, pp. 3-6.

[7] M. Boduszyński, B. R. Chadha and T. Szkuta-Pochopień, "Investigations on Romashkino Asphaltic Bitumen. 3. Fractionation of Asphaltenes Using Ion-Exchange Chromatography," Fuel, Vol. 56, No. 4, 1977, pp. 432-436. doi:10.1016/0016-2361(77)90072-2

[8] D. I. D. B. A. Yakovlev, G. A. Tuzhilin and N. V. Parfeneko "Geothermal Characteristics of The Volga-Ural Oil-Gas Province and the Romashkino Oil Field, "Petroleum Geology, Vol. 11, No. 7-12, 2001, p. 309.

[9] Q. S. Song and J. S. Zhang, "Secondary Development of
Romashkino Field," Foreign Oil Field Engineering, Vol. 17, No. 5, 2001, pp. 31-35.

[10] D. K. Nourgaliev, R. K. Muslimov, N. N. Sidorova, et al., "Variation of i-Butane/n-Butane Ratio in Oils of the Romashkino Oil Field for the Period of 1982-2000: Probable Influence of the Global Seismicity on the Fluid Migration," Journal of Geochemical Exploration, Vol. 89, No. 1, 2006, pp. 293-296. doi:10.1016/j.gexplo.2005.12.022

[11] R. N. Diyashev and Y. Q. Li, "Secondary Development of Romashkino Field Aims to Stable Production," Petroleum Exploration and Development Information, Vol. 2, 2001, pp. $65-74$

[12] X. B. Yang and Y. Feng, "Study on the Technological Development Measures of Updip-Zone of Glutenite Oil Field," HENAN Petroleum, Vol. 14, No. 6, 2000, pp. 17-19. 